\title{
Генотипическая изменчивость аминокислотного состава белков животного и растительного происхождения
}

\author{
® 2020 Рудаков О.Б. ${ }^{1}$, Рудакова Л.В. ${ }^{2}$, Букша М.С. ${ }^{2}$ \\ ${ }^{1}$ Воронежский государственный технический университет, Воронеж \\ ${ }^{2}$ Воронежский государственный медицинский университет им. Н.Н. Бурденко, Воронеж
}

Поступила в редакцию 5.01.2020 г.

DOI: $10.17308 /$ sorpchrom.2020.20/2375

В статье рассматриваются статистические данные по аминокислотному составу белков животных и растений, полученные методами ионообменной и высокоэффективной жидкостной хроматографии. Изучали состав аминокислот мяса разных животных и сои разных сортов. Для статистического анализа использовали экспериментальные данные по аминокислотному составу белков мяса бройлеров $(\mathrm{N}=208)$, баранины $(\mathrm{N}=162)$, мяса кролика $(\mathrm{N}=65)$, свинины $(\mathrm{N}=52)$, мяса гуся $(\mathrm{N}=68)$, говядины $(\mathrm{N}=46)$, мясо кенгуру $(\mathrm{N}=10)$ и креветки $(\mathrm{N}=68)$, изолята сои $(\mathrm{N}=234)$. Обсуждаются выявленные биохимические корреляции, наблюдаемые при изменении аминокислотного состава белков в зависимости от их происхождения. Существенные прямые (симбатные) корреляции ( $\mathrm{R}=0.70-0.90)$ наблюдаются между содержанием глицина, аланина и пролина с изменением состава мясных белков. Содержание фенилаланина коррелирует с содержанием аланина, тирозина и аргинина. Более тесные корреляции ( $\mathrm{R}>0.9)$, наблюдаются между аминокислотами в соевом белке. Однако эти корреляции отличаются от корреляций, характерных для животных белков. Установлены универсальные соотношения аминокислот в белках как животного, так и растительного происхождения. Это соотношения между глицином, аланином и фенилаланином, между фенилаланином и тирозином. В статье сравниваются контрольные диаграммы аминокислотного состава соевого изолята, говядины и баранины. Показано, что из-за незначительных различий в аминокислотном составе мяса и соевого изолята, по результатам аминокислотного анализа трудно идентифицировать фальсификацию мясных продуктов, в которые добавлен соевый белок в количестве менее $25 \%$. Тем не менее, найденные корреляции могут быть полезны для определения происхождения белка и выявления грубой фальсификации мясных продуктов. Они также могут быть использованы в биологических, биохимических и диетологических исследованиях.

Ключевые слова: аминокислотный анализ, белки, сырое мясо, соевый изолят, генотипическая изменчивость, ионообменная хроматография, ВЭЖХ.

\section{Введение}

Мясо - основное сырье для продуктов питания, которое содержит полноценные белки. Пищевая и биологическая ценность мяса обусловлена более или менее сбалансированным составом протеиногенных аминокислот (АК), а именно определенным соотношением незаменимых и заменимых АК, входящих в состав белков. На конкретный аминокислотный состав белков мяса оказывает влияние много факторов - генотипических и фенотипических: вид и порода животных, климат, время года, корма, пол, возраст, различные части туши (грудная часть, бедренная, длиннейшая мышца спины и т.д.) и многое другое. 
На сегодняшний день при производстве мясной продукции широко используют не только говядину, свинину, баранину, мясо птиц, но и соевую муку, концентраты, изоляты соевого белка, соевое молоко, текстурированный соевый белок. После удаления масла из соевых бобов остается обезжиренная белковая масса, являющаяся исходным материалом для трех основных соевых продуктов, содержащих от 50 до 90\% протеина. Это соевая мука или крупа, соевые протеиновые концентраты и соевые протеиновые изоляты. Соевый протеин обладает высокой питательной ценностью и, безусловно, представляет интерес в качестве источника пищевого белка. Соевый белок содержит все необходимые АК, обеспечивающие ежедневную потребность в них человеческого организма. По аминокислотному составу, в целом, соевый белок близок белкам животного происхождения. Активное применение соевых белков обусловлено так же тем, что они обладают высокими технологическими свойствами, обеспечивают связывание жира и воды, стабилизируют гетерогенные дисперсные системы (эмульсии и суспензии), улучшают текстуру продукции, уменьшают ее потери при тепловой обработке, а значит, повышают ее выход, и при этом снижают себестоимость. Частичная замена мясного сырья соевыми белками может не приводить к ухудшению вкусовых качеств продукции, при этом использование соевых белков при производстве мясных продуктов практически не требует изменения традиционных технологических процессов в соответствии с нормативной документацией [1]. Разработано и продолжается разработка все новых технических условий на продукцию с использованием соевых белков. Приведенные выше аргументы в пользу применения соевых белков (пищевая ценность, технологичность, меньшая стоимость, чем мясное сырье) создает предпосылки для недобросовестных производителей использовать соевые белки при фальсификации более дорогостоящих традиционных мясных продуктов.

Целью настоящей работы был статистический анализ массива хроматографических данных об аминокислотном составе белков животного происхождения и белков сои. Представлялось интересным установить наиболее характерные соотношения для протеиногенных АК животных и растительных белков (на примере сои) и проверить, насколько выявленные корреляции могут служить идентификации мясных продуктов и выявлению фальсификатов. Таким образом, в статье сделана попытка методом широких обобщений статистических данных по аминокислотному составу протеинов, полученных хроматографическими методами, определить, какую количественную информацию можно использовать для контроля аутентичности и качества мясного сырья. Так, в работе [2] были установлены некоторые генотипические и фенотипические зависимости и природные корреляции в составе АК белков коровьего молока и молока других животных. При сравнении диапазонов варьирования АК в коровьем молоке с данными для образца соевого молока было отмечено, что по 6 АК (глицин, аланин, метионин, цистин, аспарагиновая кислота, аргинин) белок сои выбивается из диапазонов, характерных для белков коровьего молока. Очевидно, что аналогичные зависимости и различия можно ожидать и для АК белков мяса различного происхождения и белков соевого изолята.

\section{Эксперимент}

Для статистического анализа были использованы результаты исследований, приведенные в публикациях [3-25]. Была построена электронная таблица, содержащая данные об усредненном составе аминокислот мяса бройлеров $(\mathrm{N}=208)$, баранины $(\mathrm{N}=162)$, крольчатины $(\mathrm{N}=65)$, свинины $(\mathrm{N}=52)$, гусятины $(\mathrm{N}=68)$, говядины $(\mathrm{N}=46)$, мяса кенгуру $(\mathrm{N}=10)$ и креветок $(\mathrm{N}=68)$, сои $(\mathrm{N}=234)$. Всего для анализа ис- 
пользовано 913 экспериментальных результатов, для каждого из которых в первоисточниках указано, что они получены усреднением от 3 до 5 повторных измерений при доверительном интервале $\mathrm{P}=0.95$. В табл. 1 приведены диапазоны варьирования усредненных данных по составу АК в некоторых белках. Парные корреляции определяли в табличном процессоре Microsoft Excel 2007.

Таблица 1. Диапазоны содержание аминокислот в животных белках и в соевых изолятах, \%.

\begin{tabular}{|c|c|c|c|c|c|c|c|}
\hline $\begin{array}{c}\text { Амино- } \\
\text { кислота }\end{array}$ & Говядина & $\begin{array}{c}\text { Свини- } \\
\text { на }\end{array}$ & $\begin{array}{c}\text { Гуся- } \\
\text { тина }\end{array}$ & $\begin{array}{c}\text { Куря- } \\
\text { тина }\end{array}$ & Баранина & $\begin{array}{c}\text { Крольча- } \\
\text { тина }\end{array}$ & $\begin{array}{c}\text { Соевый } \\
\text { изолят }\end{array}$ \\
\hline Глицин & $4.6-4.7$ & $-*$ & $3.1-3.9$ & $3.3-6.6$ & $3.3-6.7$ & $4.2 * *$ & $3.9-7.6$ \\
\hline Аланин & $5.1-5.2$ & - & $4.3-4.7$ & $3.8-6.0$ & $4.4-6.9$ & 6.7 & $3.0-4.5$ \\
\hline Валин & $3.5-3.6$ & $3.6-5.6$ & $3.2-3.6$ & $3.0-5.9$ & $3.4-5.5$ & $4.1-6.3$ & $3.9-10.0$ \\
\hline Лейцин & $5.2-8.4$ & $5.8-8.1$ & $5.3-5.7$ & $2.2-7.7$ & $6.8-9.0$ & $7.3-9.2$ & $6.7-9.8$ \\
\hline $\begin{array}{c}\text { Изолей- } \\
\text { цин }\end{array}$ & $2.3-5.1$ & $2.3-5.3$ & $3.1-3.2$ & $2.2-5.0$ & $4.3-9.0$ & $3.6-5.7$ & $4.3-6.7$ \\
\hline Пролин & $1.9-7.3$ & $4.2-11.5$ & $2.2-3.5$ & $2.2-3.1$ & $2.7-5.7$ & 3.6 & $2.7-6.6$ \\
\hline $\begin{array}{c}\text { Фенила- } \\
\text { ланин }\end{array}$ & $3.1-4.4$ & $3.2-4.2$ & $2.8-3.1$ & $1.7-3.6$ & $3.5-5.5$ & $2.2-3.9$ & $2.4-9.7$ \\
\hline Тирозин & $2.4-4.8$ & $2.4-4.1$ & $2.5-2.8$ & $1.8-2.8$ & $2.3-4.7$ & $1.9-3.1$ & $2.2-4.5$ \\
\hline $\begin{array}{c}\text { Метио- } \\
\text { нин }\end{array}$ & $1.7-2.3$ & $1.5-2.5$ & $2.5-2.8$ & $1.4-2.9$ & $1.9-3.4$ & $2.0-2.7$ & $1.1-2.8$ \\
\hline Цистин & $1.8-1.9$ & $1.2-1.5$ & $0.8-0.9$ & $1.1-1.4$ & $1.0-3.9$ & $0.1-1.1$ & $0.8-0.9$ \\
\hline $\begin{array}{c}\text { Аспарги- } \\
\text { новая } \\
\text { кислота }\end{array}$ & $7.6-10.4$ & $7.1-9.5$ & $5.5-6.1$ & $9.0-9.3$ & $5.0-10.6$ & 9.1 & $4.9-12.0$ \\
\hline $\begin{array}{c}\text { Глута- } \\
\text { миновая } \\
\text { кислота }\end{array}$ & $15.5-18.5$ & $16.9-$ & $12.7-$ & $10.2-$ & $8.9-15.8$ & 16.4 & $13.7-17.7$ \\
\hline Лизин & $5.8-8.1$ & $7.1-8.0$ & $5.7-6.1$ & $5.6-8.4$ & $7.6-10.0$ & $7.7-10.3$ & $1.3-7.8$ \\
\hline Аргинин & $5.7-7.5$ & $5.9-8.0$ & $4.3-4.9$ & $2.5-6.3$ & $4.7-7.2$ & $6.2-6.8$ & $6.7-9.4$ \\
\hline Гистидин & $4.2-6.4$ & $3.1-4.5$ & $2.5-2.9$ & $2.8-11.7$ & $2.1-3.9$ & $2.5-4.4$ & $2.3-8.8$ \\
\hline Серин & $3.3-5.4$ & $4.8-5.0$ & $2.7-2.9$ & $3.1-3.3$ & $3.2-5.3$ & 4.0 & $3.3-5.7$ \\
\hline Треонин & $3.8-5.7$ & $4.1-5.8$ & $3.1-3.4$ & $2.5-3.4$ & $3.6-4.7$ & $3.3-5.1$ & $2.3-4.4$ \\
\hline $\begin{array}{c}\text { Трипто- } \\
\text { фан }\end{array}$ & $1.0-1.3$ & $1.1-1.5$ & - & $0.5-0.7$ & $1.0-1.9$ & $1.1-1.6$ & $1.1-4.8$ \\
\hline
\end{tabular}

*данные в первоисточниках отсутствуют; **в первоисточниках приведены усредненные единичные данные

\section{Обсуждение результатов}

При рассмотрении данных [3-25] и других источников, опубликованных в журналах пищевого и сельскохозяйственного профиля, выявлены некоторые аналитические проблемы. В отдельных случаях они, возможно, приводят к некорректности представленных данных. Во-первых, в статьях зачастую не приводятся не только описания, но даже ссылки на использованные методики определения аминокислот, упоминается лишь метод или только прибор, на котором выполнялся анализ. Так, только в академическом издании Беларуси [20] приведен метод (ВЭЖХ), прибор, ссылка на аттестованную методику, указание на лабораторию, в которой выполнен анализ, метрологические результаты выполнения измерений. В качестве замечания можно отметить только избыточное количество значащих цифр в значениях содержания аминокислот (АК). Во всех остальных случаях представлена менее детальная 
информация. Например, в работе [22] указан метод (ВЭЖХ) и условия анализа, однако опять не соблюдено правило округления, нет метрологических характеристик. В статьях [2,4,7,8,17,23-25] не указаны ни метод, ни прибор, ни лаборатория, ни ссылка на методику анализа, приведены только данные, зачастую без метрологических характеристик. Только в двух статьях, кроме [20] указаны лаборатории, в которых выполнялся анализ. В семи статьях указан только метод и прибор - ионообменная хроматография на автоматическом аминоанализаторе. Еще в двух статьях даны ссылки на методику анализа, однако в эти ссылки не являются первоисточниками, содержащими описание аттестованных методик. Это означает, что в большинстве процитированных работ определения выполняли не сами авторы публикаций. Ими опубликованы данные анализа, выполненные по аутсорсингу в каких-то сторонних лабораториях. Возникает вопрос, аккредитованы эти лаборатории или нет? Считаем целесообразным в таких случаях указывать в публикации локацию этих лабораторий. Часто в статьях приводится не полный аминокислотный состав, а наиболее важные незаменимые аминокислоты. При использовании ВЭЖХ не удается полностью дифференцировать (разделить) все 20 протеиногенных АК, поэтому в некоторых источниках приводятся данные по сумме лейцина и изолейцина, сумме метионина и цистеина (цистина), а не по содержанию отдельных АК $[6,10]$. При гидролизе и дериватизации АК цистеин претерпевает окислительную димеризацию с образованием димера - цистина. В связи с этим чаще всего определяют его, а не цистеин. Таким образом, где-то в данных приводят цистин, а где-то цистеин, такие данные сложно сопоставлять.

Возникает определенное сомнение, что определяли в действительности авторы - цистин или цистеин. Сравнительно редко представляют данные по триптофану, поскольку при стандартной гидролизной пробоподготовке эта АК разрушается. Иминокислота - пролин также имеет свою специфику анализа, для его определения аддукт пролина фиксируют при аналитической длине волны $\lambda=440$ нм, а для других нингидринпроизводных АК - при $\lambda=570$ нм. Если у используемого детектора нет возможности регистрировать хроматограмму в двухволновом режиме, это означает необходимость дополнительного анализа только для определения пролина. Видимо из прагматических соображений заменимую АК - пролин, нередко не включают в приводимый перечень найденных аминокислот. Вместе с тем, в животных белках наибольшей вариативности подвергаются заменимые АК, но они вызывают меньше интереса у исследователей в области пищевой химии как не имеющие большой пищевой ценности. В связи с этим данные по глицину и аланину так же часто игнорируются и не приводятся в сводных таблицах. В тоже время данные по этим АК могут быть полезными при оценке качества и идентификации мяса.

Другой типичной некорректностью публикаций в научно-технических изданиях пищевого профиля, которые бросаются в глаза химикам-аналитикам, является то, что данные по процентному содержанию АК часто представляются с излишней точностью, иной раз до 4-го знака после запятой, что существенно превышает точность хроматографических методов, то есть в таких статьях не используется правило сокращения значащих цифр. На отличиях, не превышающих погрешность определений, исследователи пытаются давать сравнительный анализ состава АК, например, бройлеров, которым давали различный корм, или мяса, которое хранилось различное время в холодильниках. В последнем случае рассуждают о денатурации белков при заморозке. Первичная структура белка - последовательность остатков АК, при заморозке она не меняется, нарушаются только надмолекулярные структуры (четвертичная, третичная и отчасти вторичная), биохимические процессы резко замедляются, поэтому такого рода умозаключения о денатурации, приводящей к изменению ами- 
нокислотного состава не убедительны. Другой разговор, если речь идет о разных способах приготовления мясных продуктов, воздействуя на них пищевыми добавками и теплом.

Наличие случайных и систематических погрешностей инструментального детектирования обуславливают величины относительной погрешности определения этими методами в 16-27\% от определяемой величины (ГОСТ 34132-2017; МВИ. МН 1363-2000). Если доля той или иной АК в белке стала больше или меньше на $2.5 \%$ после проведения тех или иных изысканий, эти изменения находятся в зоне статистической погрешности. В статьях опять же не всегда указан доверительный интервал и величина выборки.

Отметим, что разделение и определение АК в настоящее время в отечественной аналитической практике принято проводить на анализаторах аминокислот методом ионообменной хроматографии (ГОСТ 34132-2017 «Мясо и мясные продукты. Метод определения аминокислотного состава животного белка»). Не только ионообменная хроматография, но и обращенно-фазовая ВЭЖХ используется для этих целей (МВИ. МН 1363-2000 «Метод по определению аминокислот в продуктах питания с помощью высокоэффективной жидкостной хроматографии»). Имеются разработки по определению АК методами газовой хроматографии и капиллярного электрофореза.

Как известно, аминокислоты - нелетучие цвиттер-ионы, некоторые из них не имеют функциональных групп, пригодных для детектирования, поэтому практически во всех случаях анализируются не сами АК, а их производные, полученные перед или после хроматографического разделения. Так, ионообменная хроматография основана на химическом взаимодействии активных групп неподвижной фазы с ионами разделяемых соединений. Перед аминокислотным анализом белки полностью гидролизуют. После их гидролиза процесс аминокислотного анализа может быть таким же, как и для свободных АК. В качестве детектора в ВЭЖХ обычно используют спектрофотометрический детектор в видимой области или флуориметрический детектор в зависимости от используемого метода дериватизации. Ионообменная хроматография с постколоночной дериватизацией с нингидрином является наиболее распространенным методом для количественного аминокислотного анализа. Нингидриновая реакция в автоматическом аминоанализаторе используется благодаря своей высокой чувствительности. Аминокислотный анализатор содержит колонку с катионообменной смолой, через которую АК проходят с разными скоростями. Элюат автоматически смешивается с раствором нингидрина, который образует с АК окрашенный аддукт, детектируемый спектрофотометром. Приемлемое разделение АК на катионообменной колонке достигается градиентом $\mathrm{pH}$ и ионной силы. Для улучшения разделения часто используют также температурный градиент. Аддукт АК с нингидрином имеет характерный фиолетовый или желтый цвет. Аминокислоты, за исключением иминокислот, образуют аддукт, имеющий максимум поглощения при $\lambda=570$ нм, а иминокислоты (пролин), образуют аддукт желтого цвета, имеющий максимум поглощения, как сказано выше, при $\lambda=440$ нм. Таким образом, продукты постколоночной реакции между нингидрином и элюируемыми из колонки АК детектируются при длинах волн 440 и 570 нм.

Кислотный гидролиз является наиболее часто используемым методом для расщепления белка перед проведением аминокислотного анализа. Между тем, метод кислотного гидролиза может повлиять на отклонение результатов анализа от истинного содержания, из-за полного или частичного разрушения некоторых АК. Если триптофан практически полностью разрушается, то серин и треонин частично, а метионин может подвергаться окислению. В то же время цистеин обычно определяется 
как цистин, но открываемость цистина как правило низкая вследствие частичного разрушения или же восстановления до цистеина.

В случае разделения смеси АК методом обращенно-фазовой ВЭЖХ со спектрофотометрическим детектированием в видимой области спектра используют предколоночную дериватизацию, например, (диметиламино)азобензолсульфонилхлоридом (ДАБС). АК, связанные с ДАБС обладают высокой стабильностью и проявляют максимум поглощения при $\lambda=436$ нм. ДАБС-аминокислоты могут быть разделены на колонке, заполненной силикагелем, модифицированным октадецильными группами (-С18) методом обращенно-фазовой ВЭЖХ с использованием градиентного элюирования и подвижной фазы, состоящей из ацетонитрила и водной буферной смеси. Этот метод позволяет проводить с одинаковой чувствительностью анализ как АК, так и иминокислот (таких как пролин).

Таким образом, оба рассмотренных стандартизованных метода имеют не только определенные достоинства, но и недостатки, например, упомянутая необходимость проведения стадий гидролиза белков и дериватизации АК, в которых возможны побочные реакции окисления, неполного взаимодействия реагента с аналитом и др. Это означает, что методы аминокислотного анализа нуждаются в дальнейшем совершенствовании.

Рассмотренный массив данных из отечественных научно-технических изданий далеко не исчерпывает имеющиеся в научной периодике результаты аминокислотного анализа, и, строго говоря, не является однозначно репрезентативным. Выводы из выполненного статистического анализа будут иметь предварительный характер, однако они должны нацелить профильных специалистов для проверки обнаруженных тенденций и трендов.

В массиве использованных данных для 18 АК белков различного животного происхождения установлены достаточно тесные линейные корреляции (табл. 2), т.е. такие, для которых степень парной корреляции $\mathrm{R}>0.70$. Даже корреляции с $\mathrm{R}>0.50$ в статистическом анализе принято считать не случайными. Как видим, глицин, аланин и пролин симбатно меняются при изменении состава белков мяса. Содержание фенилаланина коррелирует с содержанием аланина, тирозина и аргинина. Проверка наличия внутривидовых корреляций между содержанием АК в белках мяса показала, что их может быть больше, а сами корреляции теснее.

Таблица 2. Общие для всего массива данных по аминокислотному составу животных белков линейные тренды $y=a x+b$ и степени парной корреляции $R$

\begin{tabular}{|c|c|c|}
\hline Аминокислоты* $^{*}$ & Тренд & $R$ \\
\hline гли/ала & $\mathrm{y}=0.47 \mathrm{x}+3.13(1)$ & 0.862 \\
\hline гли/про & $\mathrm{y}=0.30 \mathrm{x}+2.11(2)$ & 0.680 \\
\hline гли/фен & $\mathrm{y}=0.47 \mathrm{x}+1.31(3)$ & 0.881 \\
\hline гли/арг & $\mathrm{y}=0.42 \mathrm{x}+3.39(4)$ & 0.724 \\
\hline ала/фен & $\mathrm{y}=0.80 \mathrm{x}-0.67(5)$ & 0.810 \\
\hline вал/асп & $\mathrm{y}=1.48 \mathrm{x}+1.91(6)$ & 0.701 \\
\hline фен/тир & $\mathrm{y}=0.81 \mathrm{x}+0.23(7)$ & 0.839 \\
\hline фен/арг & $\mathrm{y}=0.82 \mathrm{x}+2.70(8)$ & 0.736 \\
\hline
\end{tabular}

*Соотношение кислот $x / y$.

В табл. 3 приведены выявленные наиболее значимые корреляции в белках бараньего мяса и мяса бройлеров (курятины). В табл. 4 даны тренды для АК белков бройлеров, баранины, говядины и свинины. Внутри отдельных групп животных с одной стороны больше парных корреляций и их степени выше, что и следовало ожидать исходя из того, что в них представлены только одни виды животных. Вместе с 
тем, соотношение некоторых АК в малой выборке в группе изменяется по этой же причине незначительно, в этом случае корреляции исчезают вовсе. Найденные тренды, безусловно, необходимо уточнять на больших выборках данных. Однако в самом их наличии не приходится сомневаться. Таким образом, можно заключить, что установлено в самом общем виде наличие природных соотношений аминокислот в животных белках, которые могут быть использованы в их идентификации и контроле качества сырого мяса. Требуются дополнительные исследования для их уточнения и определения взаимосвязи между составом аминокислот и факторами воздействия на этот состав.

Таблица 3. Частные линейные тренды для АК белков бройлеров и баранины $y=a x+b$ и степени парной корреляции $R$

\begin{tabular}{|c|c|c|c|c|}
\hline \multirow{2}{*}{ Аминокислоты } & \multicolumn{2}{|c|}{ Бройлеры } & \multicolumn{2}{c|}{ Баранина } \\
\cline { 2 - 5 } & Тренд & $R$ & Тренд & $R$ \\
\hline гли/ала & $\mathrm{y}=0.50 \mathrm{x}+2.86$ & 0.700 & $\mathrm{y}=0.54 \mathrm{x}+2.74$ & 0.721 \\
\hline гли/вал & $\mathrm{y}=0.54 \mathrm{x}+1.50$ & 0.770 & $\mathrm{y}=0.59 \mathrm{x}+1.32$ & 0.626 \\
\hline гли/про & $\mathrm{y}=0.64 \mathrm{x}+0.22$ & 0.995 & $\mathrm{y}=0.64 \mathrm{x}+0.22$ & 0.995 \\
\hline гли/фен & $\mathrm{y}=0.41 \mathrm{x}+1.00$ & 0.787 & & \\
\hline гли/арг & $\mathrm{y}=0.74 \mathrm{x}+1.61$ & 0.711 & & 0.784 \\
\hline гли/асп & & & $\mathrm{y}=1.47 \mathrm{x}+0.32$ & \\
\hline ала/вал & $\mathrm{y}=0.83 \mathrm{x}-0.045$ & 0.840 & & 0.864 \\
\hline ала/про & $\mathrm{y}=0.44 \mathrm{x}+0.35$ & 0.990 & $\mathrm{y}=0.92 \mathrm{x}-0.73$ & \\
\hline ала/фен & $\mathrm{y}=0.54 \mathrm{x}-0.05$ & 0.734 & & \\
\hline ала/лиз & $\mathrm{y}=1.27 \mathrm{x}+1.10$ & 0.925 & & 0.718 \\
\hline ала/три & $\mathrm{y}=0.11 \mathrm{x}+0.10$ & 0.970 & & 0.852 \\
\hline ала/гис & $\mathrm{y}=0.49 \mathrm{x}+0.77$ & 0.826 & $\mathrm{y}=0.47 \mathrm{x}+0.45$ & \\
\hline ала/тир & & & $\mathrm{y}=0.91 \mathrm{x}-1.82$ & \\
\hline ала/сер & & & $\mathrm{y}=0.80 \mathrm{x}-0.39$ & \\
\hline
\end{tabular}

Таблица 4. Частные линейные тренды для АК белков бройлеров, баранины, говядины и свинины $y=a x+b$ и степени парной корреляции $R$

\begin{tabular}{|c|c|c|c|}
\hline Сорт мяса & Аминокислоты & Тренд & $R$ \\
\hline \multirow{2}{*}{ Бройлеры, } & вал/про & $\mathrm{y}=0.90 \mathrm{x}-0.60(9)$ & 0.928 \\
\cline { 2 - 4 } & вал/лиз & $\mathrm{y}=15.45-2.68 \mathrm{x}(10)$ & 0.658 \\
\hline \multirow{2}{*}{ Баранина } & вал/глу & $\mathrm{y}=2.08 \mathrm{x}+3.81(11)$ & 0.821 \\
\cline { 2 - 4 } & вал/лиз & $\mathrm{y}=0.87 \mathrm{x}+4.88(12)$ & 0.763 \\
\hline \multirow{3}{*}{ Говядина } & вал/про & $\mathrm{y}=0.97 \mathrm{x}-1.01(13)$ & 0.789 \\
\cline { 2 - 4 } & вал/глу & $\mathrm{y}=21.50-0.81 \mathrm{x}(14)$ & 0.885 \\
\cline { 2 - 4 } & вал/лиз & $\mathrm{y}=0.60 \mathrm{x}+4.56(15)$ & 0.715 \\
\hline \multirow{3}{*}{ Свинина } & вал/про & $\mathrm{y}=3.73 \mathrm{x}-9.20(16)$ & 0.963 \\
\cline { 2 - 4 } & вал/глу & $\mathrm{y}=22.16-0.97 \mathrm{x}(17)$ & 0.940 \\
\cline { 2 - 4 } & вал/лиз & $\mathrm{y}=0.44 \mathrm{x}+5.52(18)$ & 0.788 \\
\hline \multirow{2}{*}{ Гусятина } & вал/глу & $\mathrm{y}=2.33 \mathrm{x}+5.18(19)$ & 0.957 \\
\cline { 2 - 4 } & вал/лиз & $\mathrm{y}=1.28 \mathrm{x}+1.58(20)$ & \\
\hline
\end{tabular}

В табл. 1 приведены диапазоны содержания АК в соевых белках, обращает на себя внимание слишком большой разброс по содержанию таких АК как пролин, фенилаланин, гистидин и триптофан. Содержание метионина и цистина (реже цистеина) в источниках, как правило, приведено в виде суммы. Возможно, что некоторые заниженные результаты связаны с ошибкой определения из-за неколичественной дериватизации АК при пробоподготовке или из-за частичного разложения молекул триптофана при гидролизе белков. Отсутствие метрологической и нормативной ин- 
формации в ряде первоисточников затрудняет оценку достоверности приводимых данных. Вместе с тем, были обнаружены тенденции и тренды, которые можно уточнять и проверять в дальнейших исследованиях, но уже на этой стадии можно сделать определенные выводы и использовать их в аналитической практике.

В табл. 5 приведены выявленные генотипические соотношения аминокислот соевых белков. Для них установлено заметно больше тесных парных корреляций, чем для животных белков, при этом найденные корреляции не совпадают с корреляциями, найденными для белков животного происхождения. Практически во всех случаях наблюдаются симбатные тренды: содержание АК в таких парах варьирует прямо пропорционально.

Таблица 5. Линейные тренды для аминокислот белков сои $y=a x+b$ и степени парной корреляции

\begin{tabular}{|c|c|c|c|c|c|}
\hline Аминокислоты & Тренд & $R$ & Аминокислоты & Тренд & $R$ \\
\hline гли/вал & $1.48 \mathrm{x}-1.54$ & 0.997 & ала/вал & $2.98 \mathrm{x}-5.57$ & 0.888 \\
\hline гли/лей & $0.78 \mathrm{x}+3.87$ & 0.994 & ала/лей & $1.14 \mathrm{x}+3.10$ & 0.914 \\
\hline гли/иле & $0.47 \mathrm{x}+3.11$ & 0.943 & ала/про & $2.09 \mathrm{x}-3.19$ & 0.957 \\
\hline гли/про & $0.69 \mathrm{x}+1.32$ & 0.871 & ала/тир & $1.35 \mathrm{x}-1.80$ & 0.922 \\
\hline гли/арг & $0.50 \mathrm{x}+4.93$ & 0.980 & ала/асп & $4.33 \mathrm{x}-7.07$ & 0.939 \\
\hline гли/гис & $1.29 \mathrm{x}-2.32$ & 0.993 & ала/глу & $33.07-4.35 \mathrm{x}$ & -0.968 \\
\hline гли/тре & $0.41 \mathrm{x}+1.15$ & 0.938 & ала/лиз & $3.00 \mathrm{x}-6.90$ & 0.919 \\
\hline гли/три & $0.92 \mathrm{x}-2.17$ & 0.991 & ала/арг & $1.72 \mathrm{x}+1.30$ & 0.870 \\
\hline иле/про & $0.84 \mathrm{x}+0.99$ & 0.962 & ала/гис & $6.64 \mathrm{x}-21.65$ & 0.960 \\
\hline иле/лиз & $0.99 \mathrm{x}+0.87$ & 0.934 & ала/сер & $1.64 \mathrm{x}-1.51$ & 0.985 \\
\hline иле/три & $1.25 \mathrm{x}-3.75$ & 0.956 & ала/тре & $0.69 \mathrm{x}+0.35$ & 0.916 \\
\hline иле/арг & $1.07 \mathrm{x}+1.93$ & 0.903 & лей/иле & $0.71 \mathrm{x}-0.22$ & 0.902 \\
\hline вал/лей & $0.56 \mathrm{x}+4.22$ & 0.939 & лей/про & $0.76 \mathrm{x}-0.81$ & 0.902 \\
\hline вал/про & $0.48 \mathrm{x}+2.0$ & 0.919 & лей/лиз & $0.85 \mathrm{x}-0.61$ & 0.986 \\
\hline вал/асп & $0.27 \mathrm{x}+9.46$ & 0.912 & лей/тре & $0.44 \mathrm{x}-0.11$ & 0.944 \\
\hline вал/лиз & $0.62 \mathrm{x}+1.67$ & 0.859 & лей/три & $0.96 \mathrm{x}-4.91$ & 0.928 \\
\hline вал/тре & $0.24 \mathrm{x}+1.79$ & 0.877 & лей/асп & $1.11 \mathrm{x}+1.5$ & 0.787 \\
\hline вал/гис & $0.92 \mathrm{x}-0.82$ & 0.915 & тир/цис+мет & $0.70 \mathrm{x}-1.22$ & 0.905 \\
\hline про/асп & $1.33 \mathrm{x}+03.34$ & 0.961 & тир/сер & $1.40 \mathrm{x}-0.56$ & 0.781 \\
\hline про/лиз & $1.13 \mathrm{x}-0.03$ & 0.941 & асп/лиз & $0.70 \mathrm{x}-1.39$ & 0.928 \\
\hline про/тре & $0.54 \mathrm{x}+0.51$ & 0.894 & лиз/тре & $0.48 \mathrm{x}+0.56$ & 0.969 \\
\hline про/три & $1.31 \mathrm{x}-4.05$ & 0.932 & лиз/три & $1.17 \mathrm{x}-4.49$ & 0.959 \\
\hline
\end{tabular}

На рис. 1 и 2 приведены примеры таких трендов. Сравнительно более тесные корреляции обусловлены тем, что в изолятах соевых белков представлены белки только семян и только одной зернобобовой культуры. Понятно, что в этом плане белки мяса из разных частей туши, вида и породы животного могут по составу различаться сильнее.

Возникает вопрос, могут ли различия в составе АК и в их природных соотношениях быть использованы в идентификации белков. На рис. 3-4 для наглядности в диаграммах, (так называемых контрольных картах) диапазоны наложены друг на друга. На оси ординат отложено процентное содержание АК, а на оси абсцисс указана категория, то есть, сокращенное обозначение соответствующей АК. Видно, что диапазоны для белков сои, баранины и говядины не полностью совпадают. Аналогичную картину можно наблюдать при сопоставлении других контрольных карт. Из диаграмм на рис. 3-4 можно сделать заключение, что с одной стороны, составы животных белков и сои, действительно близки, лишь отдельные АК животных белков 
выпадают из контрольной карты для соевых белков. На границах или за границей контрольной карты соевого белка в животных белках чаще всего оказывается содержание аланина, пролина, валина, лейцина, изолейцина, фенилаланина и лизина. Сопоставления говорят также о том, что, скорее всего, некоторые сорта сои, включенные в рассмотрение, могут сильнее отличаться по АК от животных белков, чем другие сорта.

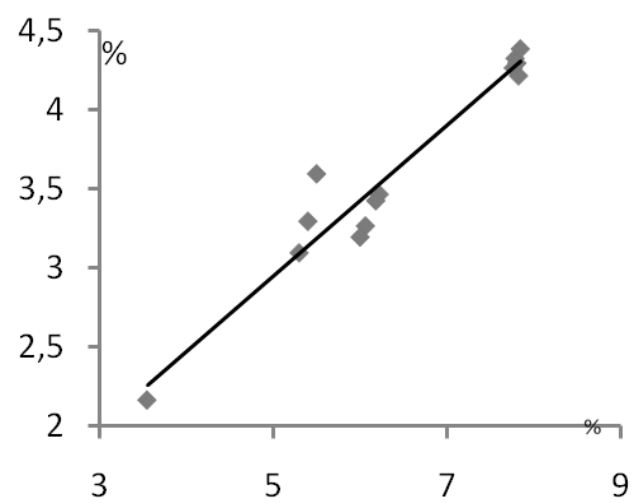

Рис. 1. Корреляция между содержанием лизина и треонина в соевом белке, $\%$

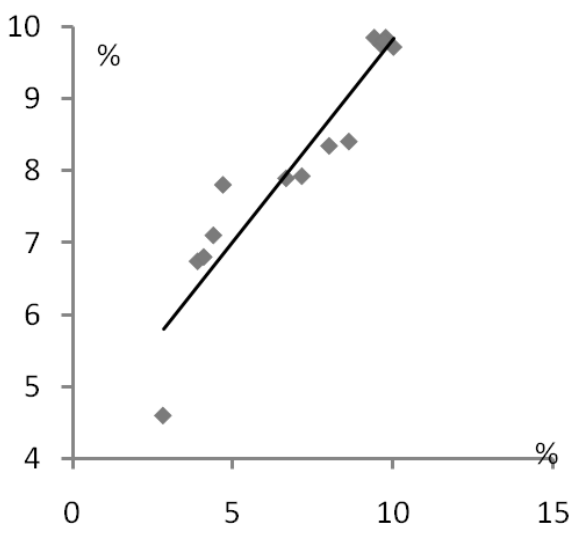

Рис. 2. Корреляция между содержанием аланина и валина в соевом белке, \%

Что касается обнаружения растительного белка в мясной продукции, здесь, по всей видимости, обнаружить соевый белок в чисто «мясном» изделии сравнением состава образца белка и контрольной карты говядины или другого мяса практически невозможно, если доля соевого белка не превышает 25\%. Выявленные различные природные соотношения АК в мясе и сое могут дать дополнительную информацию, полезную для идентификации соевого белка. Для этих целей возможно применение «нейронных сетей», обученных распознавать сумму характеристичных соотношений, или других методов анализа многомерных данных, например, метода главных компонент.

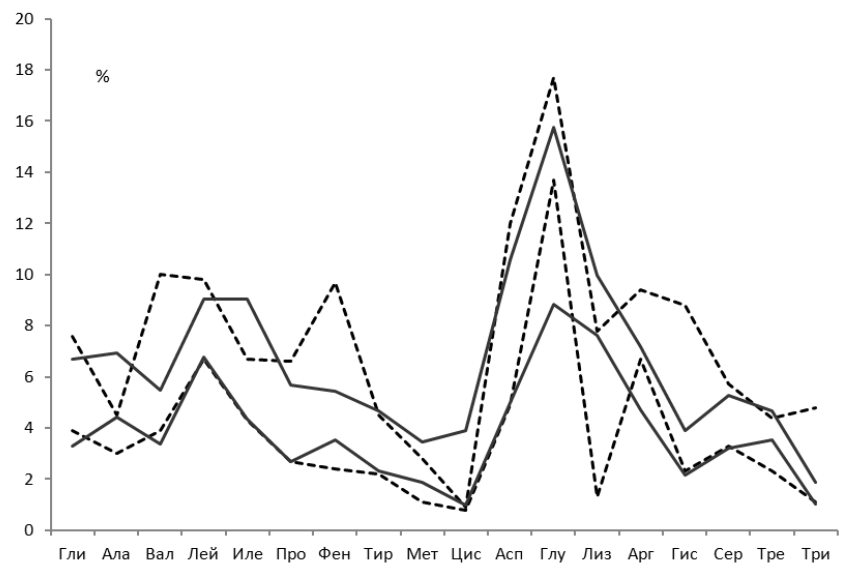

Рис. 3. Контрольная карта аминокислотного состава белков сои (штрих-линия) и бараньего мяса (сплошная линия)

Возможны и более простые способы проверки аутентичности белковой продукции. Сопоставим данные о составе АК низкомолекулярной (соя 1) и высокомолекулярной (соя 2) фракции белков сои сорта Узбек-6[22] и усредненные данные по 
составу белков говядины и баранины, по уравнениям (1)-(8) для АК $x$ рассчитали содержание АК $y$ (табл. 6). Получили весьма удивительный результат.

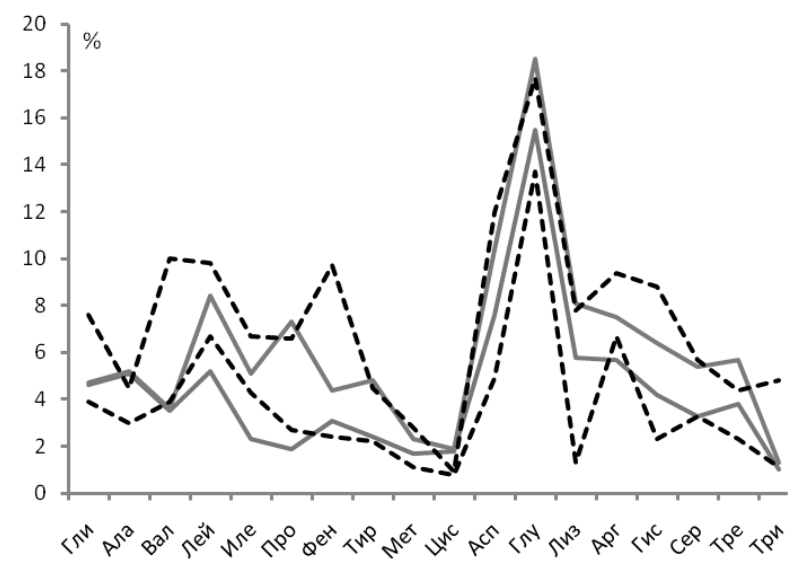

Рис. 4. Контрольная карта аминокислотного состава белка сои (штрих-линия) и белков говядины (сплошная линия)

Таблица 6. Усредненные значения содержания в белках АК (\%) и расчетные значения отдельных АК по уравнениям (1)-(8)

\begin{tabular}{|c|c|c|c|c|c|c|c|c|}
\hline $\begin{array}{l}\text { Амино- } \\
\text { кислота }\end{array}$ & Говядина & Баранина & $\begin{array}{c}\text { Соя } \\
1\end{array}$ & $\begin{array}{c}\text { Coя } \\
2 \\
\end{array}$ & $\begin{array}{c}\text { Говядина } \\
\text { (расчет) }\end{array}$ & $\begin{array}{c}\text { Баранина } \\
\text { (расчет) }\end{array}$ & $\begin{array}{c}\text { Соя } 1 \\
\text { (расчет) }\end{array}$ & $\begin{array}{c}\text { Соя } 2 \\
\text { (расчет) } \\
\end{array}$ \\
\hline Глицин & 4.7 & 5.5 & 2.4 & 3.9 & & & & \\
\hline Аланин & 5.1 & 5.8 & 1.9 & 3.0 & $5.3(1)$ & $5.5(1)$ & $4.3(1)$ & $3.1(1)$ \\
\hline Валин & 4.1 & 4.4 & 2.0 & 3.9 & & & & \\
\hline Лейцин & 6.4 & 8.1 & 3.1 & 6.7 & & & & \\
\hline Изолейцин & 3.0 & 6.5 & 3.2 & 5.5 & & & & \\
\hline Пролин & 3.9 & 4.6 & 1.8 & 2.7 & $3.5(2)$ & $3.8(2)$ & $2.8(2)$ & $2.9(2)$ \\
\hline $\begin{array}{l}\text { Фенил- } \\
\text { аланин }\end{array}$ & 4.2 & 4.5 & 1.3 & 2.40 & $3.5(3)$ & $4.0(3)$ & $0.9(3)$ & $2.4(3)$ \\
\hline Тирозин & 4.0 & 3.4 & 1.3 & 2.2 & $3.6(7)$ & 3.9(7) & 1.3(7) & $2.0(7)$ \\
\hline Метионин & 2.4 & 2.7 & 0.3 & 0 & & & & \\
\hline Цистин & 2.1 & 2.0 & $0.7 *$ & $0.5^{*}$ & & & & \\
\hline $\begin{array}{c}\text { Аспарги- } \\
\text { новая } \\
\text { кислота } \\
\end{array}$ & 8.8 & 8.1 & 8.0 & 4.9 & $8.0(6)$ & $8.4(6)$ & $4.9(6)$ & $9.2(6)$ \\
\hline $\begin{array}{c}\text { Глутами- } \\
\text { новая } \\
\text { кислота }\end{array}$ & 17.3 & 13.0 & 10.7 & 0 & & & & \\
\hline Лизин & 7.0 & 8.7 & 0.7 & 1.3 & & & & \\
\hline Аргинин & 6.8 & 6.3 & 3.6 & 6.9 & $6.1(8)$ & $6.4(8)$ & $4.4(8)$ & $8.3(8)$ \\
\hline Гистидин & 5.3 & 3.2 & 0 & 0 & & & & \\
\hline Серин & 4.4 & 4.2 & 2.7 & 3.3 & & & & \\
\hline Треонин & 4.5 & 4.3 & 1.6 & 2.3 & & & & \\
\hline Триптофан & 1.2 & 1.4 & 0 & 0 & & & & \\
\hline
\end{tabular}

* Цистеин

Оказалось, что даже при заметном отличии в содержании АК в сое и мясе их пропорции, то есть выявленные для животных белков наиболее общие соотношения (1)-(8) в первом приближении соблюдаются и в растительном белке. Хорошо совпадающие соотношения выделены в табл. 5 жирным шрифтом, совпадающие по порядку величин - курсивом. Возможно, нами найдены универсальные соотношения, характерные как для некоторых растительных, так и для животных белков. Они не 
могут служить надежными идентификаторами происхождения белка. В то же время отсутствие или пониженное содержание в белках таких АК, как метионин, глутаминовая кислота, гистидин и триптофан, может указывать на их растительное происхождение.

Обратим внимание на тренды, наблюдаемые для таких пар как валин с пролином, глутаминовой кислотой и лизином. По значениям содержания валина по уравнениям (9)-(20) (см. табл. 4) спрогнозируем содержание пролина, глутаминовой кислоты и лизина. В табл. 6 приведены усредненные содержания аминокислот в разных сортах мяса и результаты расчетов. При их хорошем совпадении расчетные значения выделены жирным шрифтом, курсивом отмечены достаточно близкие результаты, жирным курсивом - расчетные результаты, существенно отличающиеся от эксперимента. Очевидно, что для образца сои 2 корреляции 10-12 и 14-20 дают ошибочные значения, т.е. для соевого белка они не соблюдаются.

Таблица 7. Усредненные значения содержания в белках некоторых аминокислот (\%) и расчетные значения по валину трех аминокислот по уравнениям (9)-(20)

\begin{tabular}{|c|c|c|c|c|c|c|c|c|c|c|}
\hline $\begin{array}{l}\text { Амино- } \\
\text { кислота }\end{array}$ & $\begin{array}{l}\text { Говя- } \\
\text { дина }\end{array}$ & $\begin{array}{l}\text { Бара- } \\
\text { нина }\end{array}$ & $\begin{array}{l}\text { Брой- } \\
\text { леры }\end{array}$ & $\begin{array}{c}\text { Гуся } \\
\text { ся- } \\
\text { тина }\end{array}$ & $\begin{array}{c}\text { Соя } \\
2\end{array}$ & $\begin{array}{c}\text { Говя- } \\
\text { дина } \\
\text { (рас- } \\
\text { чет) }\end{array}$ & $\begin{array}{c}\text { Бара- } \\
\text { нина } \\
\text { (рас- } \\
\text { чет) }\end{array}$ & $\begin{array}{c}\text { Брой- } \\
\text { леры } \\
\text { (рас- } \\
\text { чет) }\end{array}$ & $\begin{array}{c}\text { Гуся- } \\
\text { тина } \\
\text { (рас- } \\
\text { чет) }\end{array}$ & $\begin{array}{c}\text { Соя } \\
2 \\
\text { (рас- } \\
\text { чет) }\end{array}$ \\
\hline Валин & 4.1 & 4.4 & 3.1 & 3.4 & 3.9 & \multicolumn{5}{|c|}{ Прогноз } \\
\hline \multirow{3}{*}{ Пролин } & \multirow{3}{*}{3.9} & \multirow{3}{*}{4.6} & \multirow{3}{*}{2.3} & \multirow{3}{*}{3.2} & \multirow{3}{*}{2.7} & $3.1(9)$ & $3.0(9)$ & $1.9(9)$ & $2.5(9)$ & $\begin{array}{l}2.9 \\
(9)\end{array}$ \\
\hline & & & & & & $\begin{array}{l}3.0 \\
(13)\end{array}$ & $\begin{array}{l}3.3 \\
(13)\end{array}$ & $\begin{array}{l}\mathbf{2 . 0} \\
(13)\end{array}$ & $\begin{array}{c}2.3 \\
(13)\end{array}$ & $\begin{array}{c}\mathbf{2 . 8} \\
(13)\end{array}$ \\
\hline & & & & & & $\begin{array}{c}\mathbf{6 . 1} \\
(16)\end{array}$ & $\begin{array}{c}7.2 \\
(16)\end{array}$ & $\mathbf{0}(16)$ & $\begin{array}{c}\mathbf{2 . 7} \\
(16)\end{array}$ & $\begin{array}{c}\mathbf{0 . 8} \\
(16)\end{array}$ \\
\hline \multirow{4}{*}{$\begin{array}{c}\text { Глутами- } \\
\text { новая ки- } \\
\text { слота }\end{array}$} & \multirow{4}{*}{17.3} & \multirow{4}{*}{13.0} & \multirow{4}{*}{11.7} & \multirow{4}{*}{13.2} & \multirow{4}{*}{0} & $\begin{array}{l}12.3 \\
(11)\end{array}$ & $\begin{array}{l}\mathbf{1 3 . 0} \\
(11)\end{array}$ & $\begin{array}{l}\mathbf{1 0 . 3} \\
(11)\end{array}$ & $\begin{array}{l}\mathbf{1 0 . 9} \\
(11)\end{array}$ & $\begin{array}{l}\mathbf{1 1 . 9} \\
(11)\end{array}$ \\
\hline & & & & & & $\begin{array}{l}\mathbf{1 8 . 2} \\
(14)\end{array}$ & $\begin{array}{l}17.9 \\
(14)\end{array}$ & $\begin{array}{l}\mathbf{1 9 . 0} \\
(14)\end{array}$ & $\begin{array}{l}\mathbf{1 8 . 7} \\
(14)\end{array}$ & $\begin{array}{l}\mathbf{1 8 . 3} \\
(14)\end{array}$ \\
\hline & & & & & & $\begin{array}{l}\mathbf{1 8 . 2} \\
(17)\end{array}$ & $\begin{array}{l}17.9 \\
(17)\end{array}$ & $\begin{array}{l}\mathbf{1 9 . 0} \\
(17)\end{array}$ & $\begin{array}{l}\mathbf{1 8 . 8} \\
(17)\end{array}$ & $\begin{array}{l}\mathbf{1 8 . 4} \\
(17)\end{array}$ \\
\hline & & & & & & $\begin{array}{l}14.7 \\
(19)\end{array}$ & $\begin{array}{l}15.4 \\
(19)\end{array}$ & $\begin{array}{l}\mathbf{1 2 . 4} \\
(19)\end{array}$ & $\begin{array}{l}\mathbf{1 3 . 1} \\
(19)\end{array}$ & $\begin{array}{l}\mathbf{1 4 . 3} \\
(17)\end{array}$ \\
\hline \multirow{5}{*}{ Лизин } & \multirow{5}{*}{7.0} & \multirow{5}{*}{8.7} & \multirow{5}{*}{7.2} & \multirow{5}{*}{6.0} & \multirow{5}{*}{1.3} & $\begin{array}{l}4.5 \\
(10)\end{array}$ & $\begin{array}{c}3.7 \\
(10)\end{array}$ & $\begin{array}{c}7.1 \\
(10)\end{array}$ & $\begin{array}{c}6.3 \\
(10)\end{array}$ & $\begin{array}{c}\mathbf{5 . 0} \\
(10)\end{array}$ \\
\hline & & & & & & $\begin{array}{c}\mathbf{8 . 4} \\
(12) \\
\end{array}$ & $\begin{array}{l}8.7 \\
(12) \\
\end{array}$ & $\begin{array}{l}7.6 \\
(12) \\
\end{array}$ & $\begin{array}{c}7.9 \\
(12) \\
\end{array}$ & $\begin{array}{r}8.3 \\
(12) \\
\end{array}$ \\
\hline & & & & & & $\begin{array}{c}\mathbf{7 . 0} \\
(15)\end{array}$ & $\begin{array}{c}7.2 \\
(15)\end{array}$ & $\begin{array}{c}\mathbf{6 . 4} \\
(15)\end{array}$ & $\begin{array}{c}\mathbf{6 . 6} \\
(15)\end{array}$ & $\begin{array}{c}6.9 \\
(15)\end{array}$ \\
\hline & & & & & & $\begin{array}{l}7.3 \\
(18)\end{array}$ & $\begin{array}{c}7.5 \\
(18)\end{array}$ & $\begin{array}{l}\mathbf{6 . 9} \\
(18)\end{array}$ & $\begin{array}{c}7.0 \\
(18)\end{array}$ & $\begin{array}{c}7.2 \\
(18)\end{array}$ \\
\hline & & & & & & $\begin{array}{c}6.5 \\
(20)\end{array}$ & $\begin{array}{l}7.2 \\
(20)\end{array}$ & $\begin{array}{c}\mathbf{5 . 6} \\
(20)\end{array}$ & $\begin{array}{c}\mathbf{6 . 0} \\
(20)\end{array}$ & $\begin{array}{l}\mathbf{6 . 6} \\
(20)\end{array}$ \\
\hline
\end{tabular}

Соотношения вал/глу для мяса бройлеров и гусей заметно отличается от характерных для говядины и свинины, а вот соотношения вал/лиз для всех групп жи- 
вотных близки между собой, но резко отличаются, как отмечено выше от того, что найдено для образца сои. Для животных жиров оно близко к 0.5 , а для сои равно 3.

\section{Заключение}

Статистический анализ массива данных по аминокислотному составу белков мяса и сои показал наличие значимых природных корреляций между содержанием некоторых заменимых и незаменимых аминокислот. Выявленные генотипические тренды в составе аминокислот белков мяса различных сельскохозяйственных животных и соевого изолята могут быть использованы в идентификации белков, а также в дальнейших биологических, биохимических и диетологических исследованиях.

\section{Список литературы}

1. Микляшевски П. Прянишников В.В., Бабичева Е.В., Ильтяков А.В. // Все о мясе. 2006. №3. С.10-13.

2. Рудаков О.Б., Рудакова Л.В. // Переработка молока. 2019. №11. С. 32-35.

3. Елисеева Л.И., Мартынов А.А., Гоголева П.А. // Sciences of Europe. 2019. № 37. С. 3-11.

4. Николаев С.И., Карапетян А.К., Даниленко И.Ю., Рудников В.Н. // Вестник Мичуринского государственного аграрного университета. 2019. № 1. C. 87-92.

5. Реутова Е.А. // Ученые записки Казанской государственной академии ветеринарной медицины им. Н.Э. Баумана. 2010. Т. 204. C. 236-239.

6. Буров С.В., Контарев И.В., Степаненко В.С. // Вестник Донского государственного аграрного университета. 2014. № 4-1 (14). С. 27-31.

7. Кочетков А.А. // Все о мясе. 2008. № 2. C. 22-24.

8. Тобоев Г. // Птииеводство. 2010. № 11. C. 29-30.

9. Лисицын А.Б., Чернуха И.М., Вострикова Н.Л., Горбунова Н.А. // Материалы Международной научно-практическая конференции, посвященной памяти В. М. Горбатова. 2012. T. 1. № 1. С. 226-232.

10.Шульгин Р.Ю., Приходько Ю.В., Шульгин Ю.П. // Техника и технология пищевых производств. 2014. № 4. С.81-86.

11.Давлетшина Т.А. Паулов Ю. В. // Рыбром. 2007. № 1. С. 34-36.

12.Калугин Ю. А., Балакирев Н.А., Федорова О.И. // Зоотехния. 2015. № 10. С. 43-52.

13.Авдиенко В. В., Забашта Н. Н., Головко Е. Н. // Сборник научных трудов Северо-
Кавказского научно-исследовательского института животноводства. 2017. Т. 6. № 3. С. 159-163.

14.Шехаб Т. // Мат. Международной научно-практической конференции, посвященная памяти В. М. Горбатова. 2016. № 1. С. 17-21.

15.Малтугуева М.Х., Дьячковская Л.С. // Аграрный вестник Урала. 2009. № 3 (57) С. 79-81.

16.Криштафович В.И., Маракова А.В., Суржанская И.Ю. // Мясная индустрия. 2011. № 5. C. 48-51.

17.Сазонова И.А. // Вестник современных исследований. 2018. № 4.2 (19). С. 165-166.

18.Захаров Н.Б. // Зоотехническая наука Беларуси. 2004. Т. 39. С. 46-50.

19. Седых Т.А. // Мясная индустрия. 2012. № 5. C. 50-53.

20.Петухова М.А. // Доклады Наииональной академии наук Беларуси. 2015. Т. 59. № 2. С. 118-123.

21.Дадашко В.В. Ромашко А.К., Руско А.А. и др. // Зоотехническая наука Беларуси. 2011. T. 46. № 2. C. 254-261.

22.Эшбоев Ф.Б.У., Юсупова Э.Г., Пякина Г.А. и др. // Universum: химия и биология. 2019. № 11-1 (65). C. 62-65.

23. Литвиненко О.В. // Вестник МГТУ. 2019. T. 22. № 3. C. 413-420.

24.Царегородцева Е.В. // Актуальные вопросы совершенствования технологии производства и переработки продукиии сельского хозяйства. 2018. № 20. С.191-194.

25.Попова Н.П., Белышкина М.Е., Кобозева Т.П. // Известия ТСХА. 2018. № 1. С. 104108. 


\title{
Genotypical variability of amino acid composition of animal and plant proteins
}

\author{
Rudakov Oleg B. ${ }^{1}$, Rudakova Lydmila V. ${ }^{2}$, Buksha Maxim S. ${ }^{2}$ \\ ${ }^{1}$ Voronezh State Technical University, Voronezh \\ ${ }^{2}$ Voronezh State Medical University named after N.N. Burdenko, Voronezh
}

\begin{abstract}
This paper presents statistical data regarding the amino acid composition of plant and animal proteins obtained using ion exchange chromatography and high performance liquid chromatography. In our experiments we studied the amino acid composition of various types of meat and soy. The statistical analysis was based on the experimental data on the amino acid composition of proteins of broiler chicken $(\mathrm{N}=208)$, mutton $(\mathrm{N}=162)$, rabbit meat $(\mathrm{N}=65)$, pork $(\mathrm{N}=52)$, goose meat $(\mathrm{N}=68)$, beef $(\mathrm{N}=46)$, kangaroo meat $(\mathrm{N}=10)$, prawns $(\mathrm{N}=68)$, and soy isolate $(\mathrm{N}=234)$. This paper considers the identified biochemical correlations observed when the amino acid composition of proteins differ depending on their origin. There is a strong direct (symbatic) correlation $(\mathrm{R}=0.70-0.9)$ between the amount of glycine, alanine, and proline and the changes in the composition of meat proteins. The amount of phenylalanine correlates to the amount of alanine, tyrosine, and arginine. There are closer correlations $(\mathrm{R}>0.9)$ between amino acids in soy proteins. However, they are different from those in animal proteins. The study determined the universal correlations of amino acids occurring both in animal and plant proteins. These are the correlations between glycine, alanine, and phenylalanine and between phenylalanine and tyrosine. The control diagrams of the amino acid compositions of soy isolate, beef, and mutton are compared. It is demonstrated that there is an insignificant difference between the amino acid compositions of meat and soy isolate, which makes it difficult to identify adulterated meat products by means of amino acid analysis, if the portion of soy protein in them is below $25 \%$. Nevertheless, the obtained correlations can be used to identify the origin of proteins and detect serious cases of adulteration of meat products. They can also be used in biological, biochemical, and nutritional studies.
\end{abstract}

Keywords: Amino acid analysis, proteins, raw meat, soy isolate, genotypical variability, ion exchange chromatography, HPLC

\section{References}

1. Miklyashevski P. Pryanishnikov V.V., Babicheva E.V., Il'tyakov A.V., Vse o myase, 2006, No 3. pp. 10-13.

2. Rudakov O.B., Rudakova L.V., Pererabotka moloka, 2019, No 11, pp. 32-35.

3. Eliseeva L.I., Martynov A.A. , Gogoleva P.A., Sciences of Europe, 2019, No 37, pp. 311.

4. Nikolaev S.I., Karapetyan A.K., Danilenko I.Yu., Rudnikov V.N., Vestnik Michu-rinskogo gosudarstvennogo agrarnogo universiteta, 2019, No 1, pp. 87-92.

5. Reutova E.A., Uchenye zapiski Kazanskoj gosudarstvennoj akademii veterinarnoj mediciny im. N.E. Baumana, 2010, Vol. 204, pp. 236239.

6. Burov S.V., Kontarev I.V., Stepanenko V.S., Vestnik Donskogo gosudarstvennogo agrarnogo universiteta, 2014, Vol. 14, No 4-1, pp. 27-31.

7. Kochetkov A.A., Vse o myase, 2008, No 2, pp. 22-24.

8. Toboev G., Pticevodstvo, 2010, No 11, pp. 29-30.
9. Lisicyn A.B., Chernuha I.M., Vostrikova N.L., Gorbunova N.A., Materialy Mezhdunarodnoj nauchno-prakticheskaya konferencii, posvyashchennoj pamyati V. M. Gorbato-va, 2012, Vol. 1, No 1, pp. 226-232.

10. Shul'gin R.Yu., Prihod'ko Yu.V., Shul'gin Yu.P., Tekhnika $i$ tekhnologiya pishchevyh proizvodstv, 2014, No 4, pp. 81-86.

11. Davletshina T.A. Paulov Yu.V., Rybrom, 2007, No 1, pp. 34-36.

12. Kalugin Yu.A., Balakirev N.A., Fedorova O.I., Zootekhniya, 2015, No 10, pp. 43-52.

13. Avdienko V.V., Zabashta N.N., Golovko E.N., Sbornik nauchnyh trudov SeveroKavkazskogo nauchno-issledovatel'skogo instituta zhivotnovodstva, 2017, Vol. 6, No 3, pp. 159-163.

14. Shekhab T., Mat. Mezhdunarodnoj nauchno-prakticheskoj konferencii, posvyashchennaya pamyati V. M. Gorbatova, 2016, No 1, pp. 17-21.

15. Maltugueva M.H., D'yachkovskaya L.S., Agrarnyj vestnik Urala, 2009, Vol. 57, No 3, pp. 79-81. 
16. Krishtafovich V.I., Marakova A.V., Surzhanskaya I.Yu., Myasnaya industriya, 2011, No 5, pp. 48-51.

17. Sazonova I.A., Vestnik sovremennyh issledovanij, 2018, Vol. 19, No 4.2, pp. 165-166.

18. Zaharov N.B., Zootekhnicheskaya nauka Belarusi, 2004, Vol. 39, pp. 46-50.

19. Sedyh T.A., Myasnaya industriya, 2012, No 5, pp. 50-53.

20. Petuhova M.A., Doklady Nacional'noj akademii nauk Belarusi, 2015, Vol. 59, No 2. pp. 118-123.

Рудаков Олег Борисович - д.Х.н., зав. кафедрой химии и химической технологии материалов Воронежского государственного технического университета, Воронеж

Рудакова Людмила Васильевна - д.Х.н., зав. кафедрой фармацевтической химии и фармацевтической технологии Воронежского государственного медицинского университета, Воронеж

Букша Максим Сергеевич - студент Воронежского государственного медицинского университета, Воронеж
21. Dadashko V.V. Romashko A.K., Rusko A.A. et al., Zootekhnicheskaya nauka Belarusi, 2011, Vol. 46, No 2, pp. 254-261.

22. Eshboev F.B.U., Yusupova E.G., Pyakina G.A. et al., Universum: himiya $i$ biologiya, 2019, Vol. 65, No 11-1, pp. 62-65.

23. Litvinenko O.V., Vestnik MGTU, 2019, Vol. 22, No 3, pp. 413-420.

24. Caregorodceva E.V., Aktual'nye voprosy sovershenstvovaniya tekhnologii proiz-vodstva $i$ pererabotki produkcii sel'skogo hozyajstva, 2018, No 20, pp. 191-194.

25. Popova N.P., Belyshkina M.E., Kobozeva T.P., Izvestiya TSHA, 2018, No 1, pp. 104-108.

Rudakov Oleg B. - Dr. Sci (Chemistry), head of Department of chemistry and chemical technology of materials of Voronezh state technical University, Voronezh. E-mail: robi57@mail.ru

Rudakova Lyudmila V. - Dr. Sci (Chemistry), head of Department of pharmaceutical chemistry and pharmaceutical technology of Voronezh state medical University, Voronezh. E-mail: vodoley65@mail.ru

Buksha Maxim S. - Student of Voronezh state medical University, Voronezh. E-mail: snbuk@bk.ru 